\title{
Supply Chain and Gender Relations in Ornamental Plants Business of CV. Malino Florist.
}

\author{
Vidya Febrianti', Darmawan Salman'1, Mardiana E Fachri', Sitti Bulqis², Mahyuddin², Eymal B \\ Demmalino².
}

\author{
${ }^{1}$ Agribusnis Study Program Students, Graduate School of Hassanuddin University \\ ${ }^{2}$ Lecture of Agribusiness Program, Graduate School of Hassanuddin University \\ ${ }^{3}$ Lecture of Gender and Development Program, Graduate School of Hassanuddin University
}

Correspondence Author: Vidya Febrianti, Agribusnis Study Program Students, Graduate School of Hassanuddin University, Makassar, 90245, Indonesia. E-mail: vidya@pasca.unhas.ac.id

Received date: 29 August 2019, Accepted date: 28 October 2019, Online date: 30 October 2019

Copyright: (C) 2019 Vidya Febrianti., This is an open-access article distributed under the terms of the Creative Commons Attribution License, which permits unrestricted use, distribution, and reproduction in any medium, provided the original author and source are credited.

\begin{abstract}
This study aims to determine the supply chain channel of ornamental plants, the supply chain efficiency of ornamental plants, and gender related to the supply chain process of ornamental plant. The methods used in this study were primary data and secondary data. The data were processed into three stages. the first was an analysis of supply chains of ornamental plant using a three-flow supply chain, the performance of supply chain measured with the efficiency of time use, costs and business revenues, Gender relations used analysis of equality and gender welfare to see access and control. The results indicate that the supply chain pattern of ornamental plant was classified as efficient because the total production costs incurred by the CV. Malino Florist company is IDR 50,090.996 and get a total income of IDR 44,937,004 with R/C Ratio 1.9 can be seen from the results of $\mathrm{R} / \mathrm{C}$ obtained, the plant company is classified as efficient and profitable because the R/C Ratio obtained $>1$. From harvesting activities to transportation activities with an average of 2.5 or equivalent with 10 hours carried out once a week. Access and control over resources in the production flow is controlled by male employees, while females are more dominant in financial resources and information flow. The working time spent by men is greater than women and there is a concentration of the role of women on domestic activities while external activities are controlled by men. The pattern of decision making in the company is dominated by males in the production stream while women are more dominant in administrative activities, namely in the financial and information flow. Keywords: Supply chain, ornamental plants, gender.
\end{abstract}

Keywords: Supply chain, ornamental plants, gender.

\section{INTRODUCTION}

Floriculture is one of the sub-sectors which is the centre of growth in the agricultural sector. Three reasons support the above, namely a) The potential contribution of ornamental plants that have economic value b) The market potential of ornamental plant products, both domestic and export, and c) The potential contribution of agriculture to the development of ornamental plants in Indonesia is still quite extensive. Therefore it is essential to build business partnerships that support each other, and support each other and require quality, reliable management so that the ornamental plant trade can meet market demand. Institutional partnerships are incorporated in networks or chains commonly called supply chains that distribute goods or services from producers to customers. Need to implement a good marketing strategy and technology [1]. This is supported by the opinion of Stanton in Rahmat (2016) [2], which is a large discussion strategy that discusses how companies must support to achieve success. Therefore, starting a development business through a marketing strategy because in a crisis situation, large companies have proven their ability to survive and grow in their income. Furthermore, the comparative advantage of a business lies in the ability of entrepreneurs to manage human resources, and utilize variable costs and fixed costs, including selling products at lower prices to buy them [3]. Competitiveness is related to the company's ability to innovate in products [4].

The ornamental plant business cannot replace the role of human resources in each supply chain subsystem. Men and women basically have the same potential as men and women in developing. The role of women in the productive world includes activities related to agriculture [5] but women, in general, are only considered as supplementary earners while men are considered as the main breadwinners,[6] also supports the need to improve safety above one of its effects is the marginalizat ion of women's roles. It is, therefore, necessary to review practices in the world of work, especially in the informal sector such as ornamental companies, where companies play an important role in increasing urbanization while supporting equality in local economic development [7]. 


\section{MATERIALS AND METHODS}

This research was conducted at CV. Malino Florist in South Sulawesi with the consideration that the company has a complete subsystem of upstream agro-industry to the retail outlets (downstream, processing and marketing) of the largest ornamental plants that are large enough in South Sulawesi. This study uses secondary data that includes data on the area of ornamental plant production in South Sulawesi.

Following are the steps in using qualitative analysis tools in the CV. Malino Florist ornamental plant company in South Sulawesi: a) Identifying all supply chain members and identifying relationships between supply chain members: b) Identifying supply chain configuration relationship includes managing three types of flows namely information flow, product flow and financial flow. In measuring supply chain efficiency in general, it can be explained as the integration of activities that begin with the procurement of goods and services, change raw materials into finished products, and deliver these goods to consumers in an efficient manner. In general, understanding the supply chain will mean the occurrence of material flow from the beginning to the consumer by taking into account the timeliness factors, costs and operating revenues. Analysis of income in the ornamental plant business uses the following formula

Where:

$$
\pi=T R-T C
$$

$\pi:$ Company Income $(\mathrm{Rp})$

$T R:$ Total Revenue or total company revenue $(\mathrm{Rp})$

$T C:$ Total Cost or total cost $(\mathrm{Rp})$

Revenue and Cost Ratio Analysis of the return cost ratio or $\mathrm{R} / \mathrm{C}$ is a comparison between revenue and costs. Return cost ratio is used to measure farm efficiency against each use of one input unit. The efficient criteria in this $\mathrm{R} / \mathrm{C}$ analysis are:

$\mathrm{R} / \mathrm{C}$ Ratio $=\frac{T R}{T C}$

Information:

$\mathrm{R} / \mathrm{C}$ ratio (Revenue Cost Ratio) $=$ Cost of Revenue

$T R$ : Total Revenue or total company revenue (Rp)

$T C$ : Total Cost or total cost (Rp)

a. If $\mathrm{R} / \mathrm{C}>1$, then the farm experiences a profit because the revenue is greater than the cost spent

b. If the $\mathrm{R} / \mathrm{C}$ is $<1$, then the farm suffers losses because the revenue is less than the cost

c. If $\mathrm{R} / \mathrm{C}$ is 1 , then farming gets even because the revenue is equal to the cost.

Primary data that has been obtained is then processed using a computer with the Microsoft Excel program. The analysis used to look at gender relations in this study was measured through, access, control, participation and benefits. a) The division of labor is the separation of work between individuals or groups of individuals, b) The level of access is how big opportunity that is owned by the employees of the man or woman in the process of producing ornamental plants. Measured through whom that has the chance to use resources for work in the company of ornamental plants. c) Control Level is the extent to which the capabilities of male and female employees in decision making are analyzed based on employee perceptions of behaviour in controlling resources while working in an ornamental plant company

\section{RESULTS AND DISCUSSION}

\section{Employee Characteristics CV. Malino Florist}

CV. Malino Florist has 22 employees as the number of respondents in this study. Characteristics of employees are social conditions that are broken down based on age, farming experience, gender, and level of education.

Table 1. Characteristics of Employees CV. Malino Florist in South Sulawesi, 2019

\begin{tabular}{|c|c|c|c|}
\hline No & Employee Characteristics & Number of employees & $\%$ \\
\hline \multirow[t]{5}{*}{1} & Age & & \\
\hline & $23-30$ & 20 & $90 \%$ \\
\hline & $32-40$ & - & - \\
\hline & $41-49$ & - & - \\
\hline & $50-59$ & 2 & $10 \%$ \\
\hline \multirow[t]{3}{*}{2} & Gender & & \\
\hline & Male & 15 & $69 \%$ \\
\hline & Female & 7 & $31 \%$ \\
\hline
\end{tabular}




\begin{tabular}{cccc} 
Middle School & - & - \\
SHS & 17 & $77 \%$ \\
Lecture (S1) & 5 & $23 \%$ \\
\hline $4 \quad$ Length of work & & - \\
\hline > 4 years & - & $37 \%$ \\
3-4 years & 8 & $63 \%$ \\
\hline
\end{tabular}

Source: Secondary data of CV. Malino Florist

CV.Malin Florist has a job that is almost $70 \%$ outside (in the field) the type of work is classified as heavy so it is mostly done by men. From the results of the study showed that only $31 \%$ of employees were female, there were 2 female employees who worked in the screen house (field), 2 female employees worked in the post-harvest section and 3 employees mostly worked in the back office. Malino Florist is still relatively low, reaching $77 \%$ of employees having education only up to high school le vel. But the level of education does not illustrate the management of the company less than the maximum because it is associated with decision making that dares to step into a broader scale of business, it looks like the company has changed a lot.

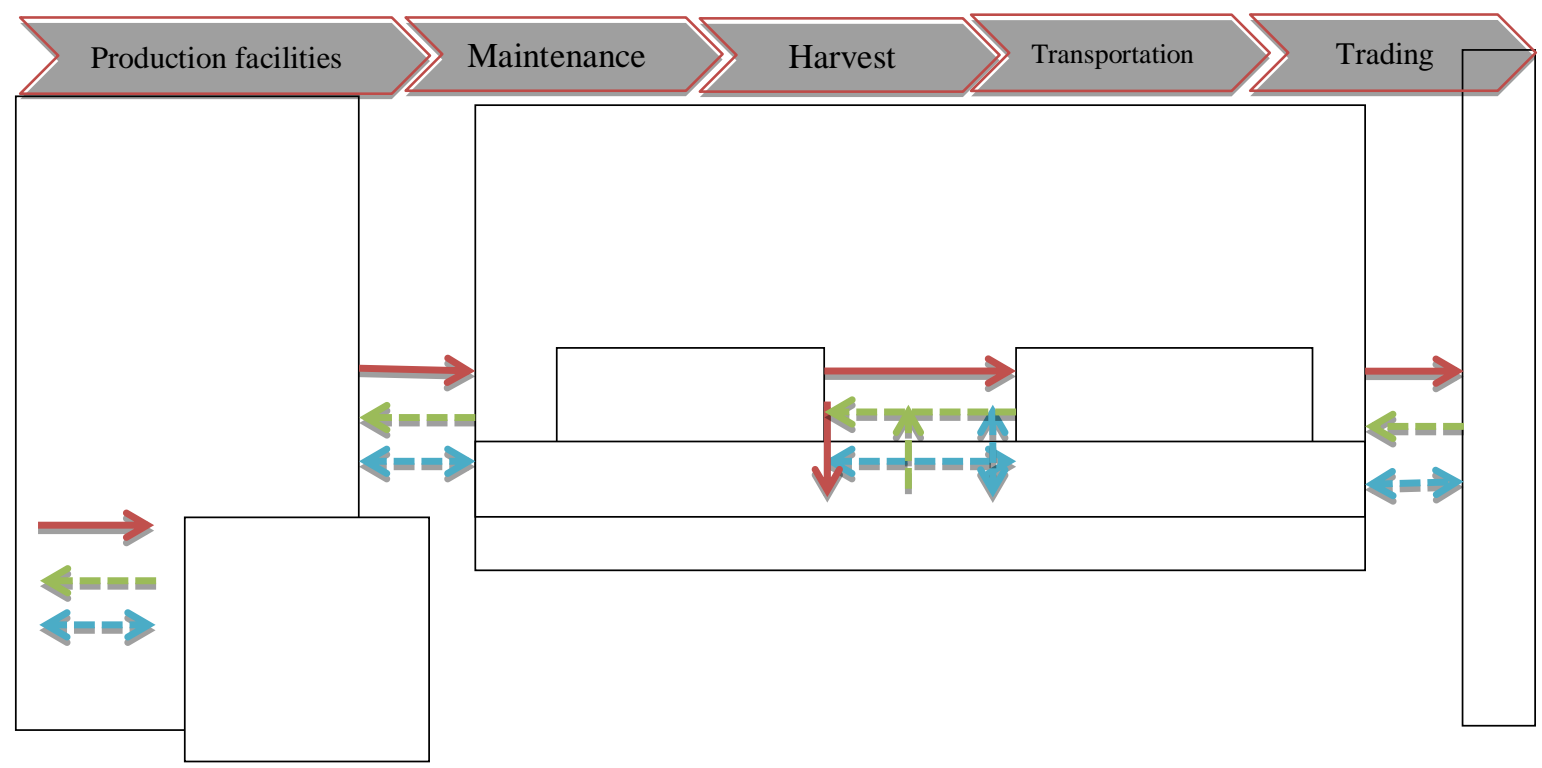

a. Product Flow

Picture 1. Ornamental Plant Supply Chain Flow Chart, CV. Malino Florist.

The products that are distributed in marketing are ornamental plants. The flow of products begins from the screen house or ornamental plant gardens. Employees plant ornamental plant seeds. Ornamental plant seeds are taken from mother plants that are self-cultivated in a tissue culture laboratory. The age of ornamental plants from seedlings to the peak of harvest (1 planting period) is 13 weeks, so in one year there are 4 periods in each screen house. After going through the process of planting up to post-harvest using a long time, ornamental plants that have been harvested will go through a sorting process, in this case, seeing the perfection of the leaf stalks and stems, after the sorting process is done semi-finished product packaging and then transported to the CV office. Malino Florist in Makassar uses a boxcar to maintain its freshness after processing or packaging of the ornamental plant reaches the consumers.

\section{b. Financial Flow}

The financial flow starts from the CV. Malino Florist is in the form of paying money for products sold, namely fresh ornamental plants from the screen house to business partners and consumers. The payment money finally forms into a cycle, because it is used as capital to return to production. Every week basic fertilizer is needed in the form of Sp- 36 fertilizer ( Rp. $1500 / \mathrm{kg}$ ) and MgSO4 (Rp. $2100 / \mathrm{kg}$ ) each as much as $240 \mathrm{~kg}$ per week or the cost of weekly fertilizer Sp-36 (Rp. 360,000) and MgSO4 (504,000). For 18 screen houses can spend 2 reams of paper per paper ream Rp. 200,000 (Rp. 400,000). Besides paper, the tape is also needed in the process of packing up to 6 rolls with a price per roll of Rp. 12,000. After harvesting the ornamental plant products then transported to the office of CV. Malino Florist in Makassar uses a boxcar that needs oil costs of Rp. 150,000 since transport. Transactions are not only done in cash or noncash, but can also be paid in advance. Initially, the ornamental plants went through a process of checking quality and weight by people who worked in the company that established partners with CV. Malino Florist and then did the recording. Furthermore, the note or evidence is given to the finance department and the finance 
department directly pays the trader CV. Malino Florist money, Facilities are a very important element in efforts to develop a business [8].

c. Information Flow

Information flowing between CV. Malino Florist can be in the form of price, quality, good cultivation methods, and the amount of production. The flow of information flows reciprocally from the company to partners to consumers and vice versa, in contrast to product flow and financial flow. CV. Malino Florist sells a variety of products, namely chrysanthemums per month, only Rp. 6,000 , can be made as a hand bouquet or table flower, then standing flower can be made as a gift or greeting for relatives in the price range starting from Rp. 500,000 wreaths board, composed by various of sizes ranging from the smallest $2 \times 1,5 \mathrm{~m}$ with the largest price Rp.350.000 up to 4x2 m Rp.1.500.000.

\section{Supply Chain Performance Efficiency}

The efficiency of ornamental plant supply chain performance is the level of supply chain ability to meet consumer needs by considering appropriate performance indicators at certain times and costs. Measurement of supply chain performance in this study is based on production costs and delivery times.

Marketing costs are costs that must be incurred for marketing purposes, incurred costs in the context of carrying out production activities within the company to the consumer. R / C Ratio is a comparison of the total receipts of ornamental plants with the total costs incurred by CV. Malino Florist. To find out which ornamental plant production is feasible or not, the Revenue Cost Ratio (R / C Ratio) method is used.

Table 2. R/C Ratio of CV. Malino Florist companies in South Sulawesi.

\begin{tabular}{|c|c|c|c|c|}
\hline No & Cost Type & $\begin{array}{l}\text { Total } \\
\text { (Unit) } \\
\end{array}$ & Unit Price (Rp) & Value \\
\hline \multirow[t]{6}{*}{1} & Fixed cost & & & \\
\hline & $>\square$ Land Lease & 1 & $8,400,000$ & $8,400,000$ \\
\hline & $>\square$ Employee & 22 & $1,300,000$ & $28,600,000$ \\
\hline & (person) & 1 & 83,330 & 83,330 \\
\hline & $>\square \mathrm{Tax}$ & 11 & 691,666 & 691,666 \\
\hline & $\begin{array}{l}>\square \text { Depreciation } \\
\text { (fruit) }\end{array}$ & & & \\
\hline \multirow[t]{18}{*}{2} & Variable Cost & & & \\
\hline & $>\square$ Electricity & 1 & 600,000 & 600,000 \\
\hline & $>\square$ Water & 1 & 300,000 & 300,000 \\
\hline & $>\square$ Call Cost & 1 & 150,000 & 150,000 \\
\hline & $>\square \mathrm{BBM}$ & 1 & 800,000 & 800,000 \\
\hline & $>\square$ Fertilizer $(\mathrm{kg})$ & 480 & 864,000 & $2,376,000$ \\
\hline & Flower Bouquet Making & & & \\
\hline & $>\square$ Cork (fruit) & 390 & 13,000 & $5,070,000$ \\
\hline & $>\square$ Glue (can) & 38 & 6,500 & 250,000 \\
\hline & $>$ Plastic flower (box) & 24 & 35,000 & 850,000 \\
\hline & $>\square$ Paper (ream) & 2 & 200,000 & 400,000 \\
\hline & $>\square$ ribbon hemp rope & 5 & 10,000 & 50,000 \\
\hline & (fruit) & 45 & 30,000 & $1,350,000$ \\
\hline & $>\square$ Baldu Fabric (meter) & 100 & 3,500 & 350,000 \\
\hline & $>\square$ Plastic (sheet) & 20 & 6,000 & 120,000 \\
\hline & $>\square$ Slotip (fruit) & 50 & 10,000 & 500,000 \\
\hline & $>\square$ Wet Cork (fruit) & & & \\
\hline & Total Cost & & & $50,940,996$ \\
\hline \multirow[t]{11}{*}{3} & Income & & & \\
\hline & $>\square$ Bouquet & 30 & 100,000 & $3,000,000$ \\
\hline & $>\square$ Standing Flower & 15 & 500,000 & $7,500,000$ \\
\hline & $>\square$ Cut Flowers & 6600 & 6,000 & $39,000,000$ \\
\hline & $>\square$ Flower Board $(2 \times 1,5)$ & 40 & 350,000 & $14,000,000$ \\
\hline & $>$ Flower Board (2x2) & 33 & 500,000 & $16,500,000$ \\
\hline & $>\square$ Flower Board (3x2) & 34 & 750,000 & $25,500,000$ \\
\hline & $>\square$ Landcape Park & - & - & - \\
\hline & Total Revenue & & & $106,100,000$ \\
\hline & Total income & & & $55,159,004$ \\
\hline & R / C Ratio & & & 2.08 \\
\hline
\end{tabular}

Source: Primary Data After Processing, 2019. 
Table 2 shows that the total marketing costs incurred by the company CV. Malino Florist Rp. 50,940,996 and get a total profit of Rp 55,159,004 with R / C Ratio 2.08, it can be seen that from the results of R / C obtained, the ornamental plant company is classified as efficient and profitable because the R / C Ratio obtained> 1.

The time needed to do an activity. This measure is very important in the context of the supply chain, especially for supply chains that are competent on the basis of response speed. The response speed is generally determined by the time required by each activity and process in the supply chain.

Table 3. Time / Duration of Distribution Activities of Ornamental Plants to the Office CV. Malino Florist

\begin{tabular}{lcc}
\hline & \multicolumn{2}{c}{ Time } \\
Company Activity & H / M / & Hour \\
\hline Harvest & B & 3 \\
Sorting & M & 3 \\
Packaging & M & 1 \\
Transportation & M & 3 \\
TOTAL & M & $\mathbf{1 0}$ \\
AVERAGE & & $\mathbf{2 . 5}$ \\
\hline
\end{tabular}

Source: Primary Data, 2019.

Abel above shows the duration of each activity of distributing ornamental plants including activities carried out by employees from harvesting activities to transportation activities with an average of 2.5 or equivalent to 10 hours which is done once a week. The basic concept of "Just In Time" in the supply chain is to emphasize the accuracy and time of arrival of materials in accordance with consumer demand from suppliers to the hands of consumers as determined.

\section{Gender Relations in Ornamental Plant Companies CV. Malino Florist}

a. Access and Control of Resources

Access to resources is an opportunity/opportunity for company members (both men and women) for resources that support the production process of ornamental plants, including the natural resources they have. In this study, the intended resource consists of product flow, financial flow and information flow. Control over resources can be interpreted as a pattern of employee decision making over resources in the ornamental plant business. The types of employees are generally core employees so in this study the employee members involved in the ornamental plant business are male employees and female employees.

1. Table 5. Percentage of access and control of 22 Ornamental Plant Employees in the

2. CV. Malino Florist, 2019.

\begin{tabular}{lrrrrrr}
\hline \multirow{2}{*}{\multicolumn{1}{c}{ Resource }} & \multicolumn{3}{c}{ Access } & \multicolumn{5}{c}{ Control } \\
\cline { 2 - 7 } & \multicolumn{1}{c}{ M } & \multicolumn{1}{c}{ F } & \multicolumn{1}{c}{ T } & M & F & \multicolumn{1}{c}{ T } \\
\hline Product Flow & & & & & & \\
Planting seeds & 72.73 & 9.09 & 27.27 & 63.64 & 18.18 & 18.18 \\
Giving fertilizer & 27.27 & 18.18 & 54.55 & 22.73 & 22.73 & 54.55 \\
Sprinkling & 68.18 & 9.09 & 22.73 & 63.64 & 9.09 & 27.27 \\
Pest Control & 50 & & 50 & 50 & & 50 \\
Harvest & 63.64 & & 36.36 & 63.64 & & 36.36 \\
Sorting & 36.36 & 13.64 & 50 & 36.36 & 13.64 & 50 \\
Packaging & & 59.09 & 40.91 & 18.18 & 36.36 & 45.45 \\
Transportation & 68.18 & & 31.82 & 72.73 & 13.64 & 13.64 \\
Financial Flow & & & & & & \\
Capital Influx & 81.82 & 9.09 & 9.09 & 50 & 22.73 & 27.27 \\
Cost of goods sold & 27.27 & 31.82 & 40.91 & 45.45 & 36.36 & 18.18 \\
Operating costs & 27.27 & 45.45 & 27.27 & 27.27 & 18.18 & 54.55 \\
Information Flow & & & & & & \\
Product Amount & 77.27 & 9.09 & 13.64 & 27.27 & 27.27 & 45.45 \\
Income & & 27.27 & 72.73 & 90.91 & & 9.09 \\
& & & & & &
\end{tabular}



Spending
45.45
54.55
36.36
63.64

Note: $M=$ Male,$F=$ Female, $T=$ together

Access to the flow of production dominated by men following the table 10 is equal to 72.73 percent at the stage of planting, 68.18 percent in stages watering, 63.64 per cent at the stage of harvest, and 68.18 per cent in the transport stages.

Financial flow in the ornamental plant business CV. Malino Florist consists of capital inflows, cost of goods sold, and operating costs. Men dominate access to financial flows in accordance with the percentage of capital entry of 81.82 percent while the rest can be accessed by women and accessed together. The dominance of men at the stage of capital entry is due to the ownership of ornamental plant businesses owned by men so that participation in the process of capital entry is more dominantly accessible to men.

Information flow on ornamental plant business CV. Malino Florist consists of the amount of product, income and expenditure. Access to the number of products is still dominated by men in accordance with a percentage of 77.27 percent, women's access to the number of products by 9.09 percent, and shared access by 13.64 percent.

b. Division of work

The division of labor in ornamental plant companies CV. Malino Florist can be seen based on the time and labor spent at the company. Based on table 5, it is known that the amount of time spent working for men is greater than for women in carrying out activities as a company. The total work hours of men per month amounted to 68.72 percent, while women reached 31.28 percent. Spending time for men is dominant in water activities. The high level of time spent by men on watering activities is caused by cultural values which assume that men "fit" to work in these activities. In general, male companies carry out field activities.

Table6. Employees of Ornamental Plant Companies CV. Malino Florist

\begin{tabular}{|c|c|c|c|c|c|c|c|}
\hline \multirow[b]{2}{*}{ Company Activity } & \multicolumn{2}{|c|}{ Labor } & \multicolumn{2}{|c|}{ Time } & \multirow{2}{*}{$\begin{array}{c}\text { Total J am p er } \\
\text { Month }\end{array}$} & \multicolumn{2}{|c|}{ Total hour } \\
\hline & $\mathbf{M}$ & $\mathbf{F}$ & $\begin{array}{c}\mathbf{D} / \mathbf{W} / \\
\mathbf{M}\end{array}$ & Hour & & L. & P. \\
\hline Planting & 8 & 4 & $\mathrm{~B}$ & 4 & 48 & 32 & 16 \\
\hline fertilizer application & 3 & 2 & $\mathrm{M}$ & 4 & 80 & 48 & 32 \\
\hline Sprinkling & 4 & & $\mathrm{H}$ & 2 & 240 & 240 & \\
\hline $\mathrm{P}$ engontrolan pests & 4 & 2 & M & 1 & 24 & 16 & 8 \\
\hline Harvest & 8 & 4 & M & 3 & 144 & 96 & 48 \\
\hline Sorting & 2 & 3 & M & 3 & 60 & 24 & 36 \\
\hline Packaging & 3 & 2 & M & 1 & 20 & 12 & 8 \\
\hline Transportation & 4 & & M & 3 & 48 & 48 & \\
\hline M asuknya capital & & 1 & $\mathrm{~B}$ & 0.5 & 0.5 & & 0.5 \\
\hline Sales & 1 & 1 & $\mathrm{H}$ & 0.5 & 30 & 15 & 15 \\
\hline $\mathrm{H}$ arga principal & 1 & 1 & B & 0.5 & 1 & 0.5 & 0.5 \\
\hline B iaya operational & 1 & 1 & M & 0.5 & 4 & 2 & 2 \\
\hline K Quality of product & 1 & 1 & M & 0.5 & 4 & 2 & 2 \\
\hline The number of products & & 1 & $\mathrm{~B}$ & 2 & 2 & & 2 \\
\hline Spending & 1 & 1 & $\mathrm{H}$ & 0.5 & 30 & 15 & 15 \\
\hline Total & & & & & & 550.5 & 185 \\
\hline
\end{tabular}

Note: $\mathrm{M}=$ Male , F=Femle, $\mathrm{D}=$ Day, $\mathrm{W}=$ Week, $\mathrm{M}=$ Month

Developing the opinion of Sajogyo (1981), patterns of decision making in companies can be classified into five categories : (1) decisions are made by women alone without involving men; (2) decisions are made jointly by men and women but women's influence is greater; (3) decisions are made together and valued by men and women (with no signs that one has a relatively greater influence); (4) decisions are made jointly by men and women but women's influence is greater; and (5) decisions are made by men alone without involving women. 
Table 7. Decision Making Patterns in CV. Malino Florist

\begin{tabular}{lccccc}
\hline \multirow{2}{*}{ Decision-Making Sector } & \multicolumn{5}{c}{ Decision maker } \\
\cline { 2 - 6 } Wheel flow & MA & FA & JE & DM & DF \\
Planting & 81.80 & 9.10 & 9.10 & & \\
fertilizer application & & & 31.80 & 68.20 & \\
Sprinkling & & & 31.80 & 68.20 & \\
pest control & 22.75 & 22.75 & 54.50 & & \\
Harvest & 36.40 & & 63.60 & \\
Sorting & 36.40 & 45.50 & 18.1 & \\
Packaging & & 54.50 & 45.50 & \\
Transportation & 81.90 & & 18.10 & & \\
Financial flow & & & & & \\
capital inflows & 100 & & & & \\
Sales & & & 45.50 & 54.50 & \\
cost of goods sold & & & 54.50 & & \\
operating costs & 77.30 & 13.60 & 9.10 & & \\
information flow & & & & \\
product quality & & 18.20 & 63.60 & & \\
number of products & 22.75 & 31.75 & 45.50 & & \\
Spending & & 45.50 & 45.50 & & \\
\hline
\end{tabular}

Note: $\mathrm{MA}=$ Male Alone, FA= Female Alone, JE = Joint Equal, $\mathrm{DM}=$ Dominant Male, DF $=$ Dominant Female.

In table 7, it is known that the decision-making process of product flow in the company is generally done by men themselves (MA) with a percentage of 81.80 percent on planting, 81.90 percent on transportation. In terms of packaging and sorting, the dominant is done by the female (FA). Control of pests, harvests, cost of goods sold, product quality, quantity and quantity of products is largely carried out equally (JE). This is considered to be the joint responsibility of employees for the future survival of the company. The pattern of decision making on financial flows in the form of determining the entry of capital with a percentage of 100 percent and 77.30 percent of operational costs is done by men themselves (MA) this is caused by the status of ownership of companies owned by men.

\section{CONCLUSION}

Ornamental plant supply chain flow is characterized by product flow, financial flow and information flow, reciprocal flow and has a chain that is not long enough.

Ornamental plant supply chain patterns are quite efficient because the total production costs incurred by the company CV. Malino Florist Rp. 50,090,996 and get a total profit of Rp 44,937,004 with R / C Ratio 1.9, it can be seen that from the results of $\mathrm{R} / \mathrm{C}$ obtained, the ornamental plant company is classified as efficient and profitable because the R / C Ratio obtained $>1$. Harvesting activities to transport activities with an average of 2.5 or equivalent to 10 hours conducted once a week. Access and control over resources in the production flow is predominantly controlled by male employees, while women are more dominant in the financial flow and information flow resources. The time spent working for men is greater than for women and there is a concentration of the role of women in domestic activities while external activities are controlled by men. The pattern of decision making in a company is predominantly male in the flow of production while women are more dominant in administrative activities, namely in the flow of finance and information.

\section{REFERENCES}

[1] Ramchandra, M. V. 2019. Challenges of Micro and Small Scale Food Industries -A Study of Amednagar District, Maharashtra. AENSI Publication: The Research Journal of Social Sciences, 10 (6).

[2] Rahmat, Muhammad. 2016. Strategi Pemasaran Kripik Dangke di Kabupaten Enrekang (Tesis). Makassar: Universitas Hasanuddin.

[3] Sirajuddin, S. N., Siregar, H., Amrawaty, A. 2013.Comparative Advantage Analysis on Self Dependent and Business Partnership of Dairy Farmers. American-Eurasian Journal Of Sustainable Agriculture(AENSI), 10 (2): 165-170.

[4] Munizu, M., Pono, M., Alam, S. 2019. The Impact of Information Technology Application on Supply Chain Integration and Competitive Advantage Indonesia: Fishery Industry Context. Quality Access to Success, 20 (169), pp. 151-156 
[5] Siti Nurlaelah,St.Rohani, Sitti Nurani Sirajuddin 2018. The Allocation time of Women to Livestock Business in Takalar Regency of South Sulawesi Province, Indonesia. American-Eurasian Journal Of Sustainable Agriculture(AENSI), 12(2)

[6] Salman, D., 2017. The Dynamics of Farming Communities. Makassar, Ininnawa.

[7] Khadim, E. H. Choudhury, S. R. D. 2018. Motivational Factors of Entrepreneurship in Micro and Small Enterprises: An Empirical Study in Cachar District of Assam. AENSI Publication: The Research Journal of Social Sciences, 9 (9)

[8] Mardiana EF., 2016. Business Management Improvement, Product Diversification and Marketing Strategy of "Khanza Gaza" Group in Makassar City. Socio-economic journal of the fisheries and marine faculty of Hasanuddin University 